\title{
Parental Prominence, Student Housing Quality and Academic Success among Public Universities Students in Southwest, Nigeria
}

Taofik, Olatunji Bankole, (M.Sc.)

Department of Demography and Social Statistics, Faculty of Social Sciences, Obafemi Awolowo University, Ile-Ife, Nigeria

Christiana Oyeronke Paramole, (MA)

Department of Educational Foundations and Counselling, Faculty of

Education, Obafemi Awolowo University, Ile-Ife, Nigeria

Stephen, Ishola Babatunde, (M.Sc.)

Department of Psychology, Faculty of Social Sciences, Obafemi Awolowo University, Ile-Ife, Nigeria

Vivian, Ifeoma. Onwuka (M.Sc.)

Department of Mass Communication, Faculty of Social Management

Sciences, Olabisi Onabanjo University, Ago-Iwoye, Nigeria

Doi: 10.19044/ejes.v6no1a6

URL:http://dx.doi.org/10.19044/ejes.v6no1a6

Abstract

University education, if properly managed remains an appropriate mechanism through which human and nation development could be attained. In spite of numerous studies that have explored academic performance in Nigeria, the contributions of parental prominence and student housing quality on academic success are yet to be explored in the nation's public universities. This study addresses this gap by raising this question: to what extent does parental prominence and student housing predict the attainment of academic success among university undergraduates? The cross-sectional survey design, with multi-stage and purposive sampling technique was adopted. Primary information was sourced from 426 final year students of OAU, OOU and AAUA. The outcome variable of this study was academic success; and it was measured by student's attainment of outstanding or weak academic success. The key explanatory variables were parental prominence and student housing quality. Multivariate rank ordered-logistic regression and ANOVA was applied using Stata 14. Results showed that academic success was negatively associated with student housing quality. Also, results showed that parental prominence (marital status, employment status, gender preference, occupation type) were statistically associated with academic success. Results further 
showed that student housing quality and financial supports contributed about $9 \%$ to academic success. The study concluded that the challenges posed by inadequate and poor student housing facilities, lack of adequate financial supports for university students, parental gender preference in meeting-up with education needs of their children must be addressed in order to stimulate the attainment of outstanding academic success among students of public universities in Southwest, Nigeria.

Keywords: Academic success, parental prominence, student housing, public university.

\subsection{Introduction}

The term academic success is a relative word; and its acceptable definition could be attributed to what is sought to be explained or captured. Generally, academic success entails the demonstrated capability to execute, accomplish and excel in academic activities. Meanwhile, the quality of education could be influenced by a series of factors, notable among these factors are the parental prominence of students and the quality of student housing. In Nigeria, university education is most sought-for among the tertiary education applicants. Therefore, the demand for university education in the country has relegated other forms of tertiary education to the secondary list. The precedence placed on university education ahead of other forms of tertiary education is not only conceived by young school leavers who seeking admission into higher institution of learning in the country but also by their parents or guardians. Therefore, many parents in the country preferred their children to be trained in the universities to polytechnics or colleges of education. However, as a result of the prevailing poor socioeconomic status of many parents and the exorbitant fees demanded by private universities in the country, many parents preferred their children to be educated in the country's public universities (Adama, Aghimien \& Fabunmi, 2018). Consequently, the rise in the number of students that were admitted into government-owned universities on yearly basis has brought about a significant negative effect on the inadequate existing over-utilised students' hostel facilities in these institutions (Adama et al., 2018; Ekundayo, 2015; Amole, 2005).

Studies exploring academic success among university students in Nigeria have largely attributed students poor academic performance to a set of complex factors, among which were parental socioeconomic condition, poor quality of teaching, environmental factors, poor attitude of students towards their academics and students engagement in risky health behaviours such as alcoholism, drug abuse and cultism (Oviawe, 2016; Ekundayo, 2015; Oluremi, 2013; Fasokun, 2010; Mutsotso \& Abenga, 2010). Ekundayo (2015) argued that a significant number of students in the country's public universities would 
have performed better at the completion of their studies if they had been provided with the enabling facilities, most especially, decent hostel and access to financial supports.

The impact of finance on student's academic success cannot be over disregarded. Alokan, Osakinle \& Onijingin, (2013) and Fasokun (2010) maintained that students with access to adequate financial supports from their parents have little or no worries. Hence, these authors argued that students with adequate financial support were more likely to concentrate on their studies compared to students with little or no access to such financial opportunities. Similarly, it was arguably maintained by Memory \& Memory (2013), Fasokun (2010) and Nwanze (2012) that sometimes the inability of students to graduate in with good grades could be attributed to the financial hardship that these students were subjected to during their studies. According to Memory \& Memory (2013) the financial constraints that many students in the country's institutions were confronted with would have been reduced significantly if there had been a functional and regular financial supports in forms of scholarship, bursary or grants to university students from the government.

Also, studies on academic performance have established the existence of an inverse relationship between family size and resource allocations among household members. Explicitly, the argument was tiled towards the inability of households with larger members to meet up with the basic needs and rights (education right inclusive) of the children (Okeyim, Ejue \& Ekenem, 2013; Yan, 1999). Based on this assertion, it is empirical appropriate to envisage that university students from extended families, especially those from large households and with limited carrying capacity are often deny of the needful financial and monetary supports which could enhance their study comfort. Meanwhile, the absence of these supports, many a time do affect the performance of these less privileged students in schools. Also, the impact of environmental factor cannot be left out from effective learning. Therefore, adequacy and functionality of basic student housing facilities and general learning facilities such as electricity supply, water supply, effective transportation, well-equipped public libraries, and internet facilities are less readily available to students from rural neighbourhood compared to students from the cities and big towns (Dervarics \& O’Brien, 2011; Grandvaux, 2002; Yan, 1999; Lamborn, Brown, Mounts \& Steinberg, 1992). The argument here is that, students from rural areas are less likely to have access to basic amenities, and these definitely would affect their studying habit during holiday or when circumstance warrants that they are kept out of school for a longer than expected period of time.

Students housing serves as ground for socialization and place of learning. Thus, students housing plays some significant roles on students' 
psychosocial wellbeing, health, comfort and safety. In line with this assertion, Dervarics \& O'Brien, 2011; Choi (2005) insisted that the interactional effects of all the aforementioned, in one way or the other influence students' academic success. It is therefore imperative that students, especially those studying for college degree or diploma deserve a conducive and enabling environment in order to get the best out of them, academic wise. The implications for the denial with adequate and quality hostel facilities were evident in the quality of certificate earned, and the inability of many of these fresh graduates to perform properly in their places of works (Daniel, 2016; Dervarics \& O’Brien, 2011; Conley, 1999). Studies have shown that the provision of conducive, operational and a comforting living arrangement for students of higher institutions was mandatory (Ekundayo, 2015; Adunola, 2011; Kuh, Kinzie, Schuh, Whitt, 2010). These scholars maintained that the provision of adequate student hostels with functional facilities played significant contributive roles in the development of a sound state of mind in the students. It was argued by Daniel, (2016) and Kuh et al.,(2010) that the provision of housing for tertiary institution students should beyond just trying to meet students physical safety in a confined place; also attention should be made for the promotion of the health welling, social and behavioural steadiness of students.

According to EDUCAUSE (2009), students housing remained one of the key indicators used in the measurement of tertiary education standard. In Nigeria, the poor state of students' hostel core facilities were so pathetic that it was inhumane to have students confined in such dilapidating structures (Daniel, 2016; Okeyim et al., 2013). The condition of core facilities in most of the public tertiary institutions in Nigeria remained one of the major challenges that were hindering effective learning among university students in the country (Okeyim et al., 2013; Adunola, 2011). The unjustifiable state of students hostel in the country's universities were negatively heightened with the continuous increase in the number of new students that are admitted on yearly bases in the nation's public universities. Agreeably, many of the public universities in Nigeria were faced with the challenges of shortage of student housing, especially for the newly admitted students (Adunola, 2011). Also, Daniel (2016) and Ekundayo (2015) maintained that provision of adequate and an up-to-date hostels with functional core, enabling and supportive facilities (which are also affordable) would enhance effective learning thereby promoting academic excellence among university students in the country. In line with this assertion, the enhancement of qualitative university education may only be achieved if the government and other stakeholders in the educational sector put university funding on their priority list.

Therefore, adequate provision of affordable, conducive, comforting students' housing for at least three in every four university students in Nigeria is indeed an uphill task that cannot be handled by universities' administrators 
in the country. More so, with the persistent but failed strikes embarked upon by the country's university academic staff union, with their agitations for more funding of the country's public universities. It is imperative that the upgrading of public universities in the county to globally competing tertiary institution might not be on the priority list of the Nigerian government. It is therefore expedient that this study investigate the contributive influence of parental prominence and student housing on academic success among final year students of selected public universities in Southwest Nigeria.

\subsection{Statement of Problem}

The role played by financial, monetary and parental supports could undermine the extent of achieving academic success among university students. Grave (2010) maintained that students that allotted lesser time to their studies were less likely to perform exceedingly well in their studies compared with those that had substantive time allotted to studies, especially on daily basis. In line with Grave (2010) observation, Kolawole \& Boluwatife, (2016) and Nimako \& Bondinuba (2013) maintained that students with poor background or those whose educational needs were less catered for, and consequently performed poorly in their studies.

According to the California State University, brochure guide on academic excellence; referenced "the key to your future"; academic excellence goes beyond graduating with outstanding grades from college rather it is an embodiment of maximum development of student's intellectual capabilities and skills in their preparatory towards effective service delivery in their future life endeavours, especially as required of them in their field of specialization. The implications of poor academic standard as a result of financial and economic incapacitation is manifestation of the "unemployable" cry of university graduates by many employers of labour in Nigeria (Daniel, 2016; Arum \& Roksa, 2011; Yilmaz-soylu \& Akkoyunlu, 2009; David, 1996).

Another bottleneck to academic success in Nigeria was the inadequacy and the poor quality of student housing across public universities in the country (Adama et al., 2018; Akinpelu, 2015; Ekundayo, 2015). Student housing is yet to receive adequate attention as expected of the government and other major stakeholders in the educational sector. The poor attitude of the government towards the proper funding of education in Nigeria have been attributed to prioritising of larger proportion of the country's resources to other sectors of the economy which were found more pressing (Memory \& Memory, 2013). Also, the less attention given to the urgent needs of the educational sector in the country has been allied to the mismanagement of the country's scare resources (Memory \& Memory, 2013).

In spite of this precarious situations, there is a dearth of studies that have explored the contributory effects of parental prominence, and the 
deteriorating condition of student housing facilities in the nation's public universities. The attention of contemporary studies addressing the state of academic decadence in Nigeria has extensively been focused on effectiveness of teachers, shortage of teaching materials, use of obsolete facilities and administrative lapses (Adamu et al., 2018; Oviawe, 2016; Owolabi, 2015; Ajayi, Nnwosu \& Ajani, 2015). Studies addressing academic performance across universities in Nigeria although have explored student housing as a predictor of academic success, these studies have limited their studies' focus to housing shortage. Therefore, the aspect of student housing facility quality is yet to be intensively investigated. Also, these studies have not addressed the association between parental prominence and academic success. Hence, this study addresses this gap by raising the question: to what extent does parental prominence and student housing influence attainment of academic success among final year students in public universities in Southwest, Nigeria.

\subsection{Objectives of the Study}

The broad objective of this study is to investigate the combined significance influence of parental prominence and student housing qualities on academic success among undergraduates of selected public universities in Southwest, Nigeria.

The specific objectives of the study are to:

1. Investigative the association between parental prominence and academic success;

2. Investigate the association between student housing and academic success.

3. Assess the quality of student housing facilities.

1.4 Theoretical Focus: This study is underpinned by the social cognitive theory by Ludwig

Von Bertalanffy (1940’s) and the system theory by Albert Bandura (1986)

\subsubsection{The System Theory}

The system theory proposed by Ludwig Von Bertalanffy (1940’s) and furthered by Ross Ashby (1956) postulates higher institutions of learning as social system whereby students and workforce are identified as integrated interdependent units which consist of management of such parts as curriculum, student personnel, staff personnel, funds, school machineries and school community relations (Ndoma; Rugimbana and Nwankwo, 2003). The system theory is found to be in concomitant with the identified precepts, because it addresses student in higher institution of learning as an integral part and parcel of the learning institution; also, it identifies the provision of student 
housing to university scholars as a vital capacity of universities' administration and management. Imperatively, this is an indication that dearth of student housing and poor maintenance of the existing ones may jeopardize the efficient operational of the entire system. Academic failure, as a result of inadequate provision of student housing, and poor maintenance of the available ones may also affect institution's global ranking (Hazelkorn, 2015). Hence, the system theory is relevant to this study for the reason that provision of student hostel is an integral unit of higher institutions of learning.

\subsubsection{The Social Cognitive Theory}

Unlike, the system theory, the social cognitive theory, propounded by Albert Bandura (1986) postulates that learning emerges in a social context with a dynamic and mutual interaction of the persons, environment, and behaviour. The social cognitive theory identifies human behavioural attitude in relation to the effects susceptible by individual factors, conservational factors, and persistent interaction among people in their community. This theory is found to be relevant to the actualisation of the objectives of this study. Thus, parental prominence plays an undeniable role in the academic success of a child (Alokan, Osakinle \& Onijingin, 2013). For instance, students whose parents are not able to meet-up with their academic economic and financial needs are often forced to seek for alternative means in order to finance their education themselves. Consequently, no matter the academic quality predisposed to be offered by the institutions attended by such less privileged students, their academic success may be jeopardized due to parental incapacity in meeting-up with their academic economic and financial needs. Also, as propounded by Albert Bandura in his theory, human behaviour is assumed to be shaped as a result of interactions with people in his environment, and this begins with his immediate family members (parents inclusive). Thus, parental prominence, which expanse from economic situation to family structure goes a long way in providing for the general wellbeing of their family members these, obviously include meeting-up with their children's schooling needs. Therefore, attainment of academic success by university students, particularly at the undergraduate level could be significantly influenced by family structure (polygamy/monogamy), household wealth, parental level of educational attainment, place of residence and family size.

Hence, this study is underpinned by the system theory and the social cognitive theory because these theories address student in higher institution of learning as an integral part and parcel of the learning institution, provision of student housing to university scholars is identified as a vital capacity of universities' administration and management; and that that learning emerges in a social context with a dynamic and mutual interaction of the persons, environment, and behaviour. 


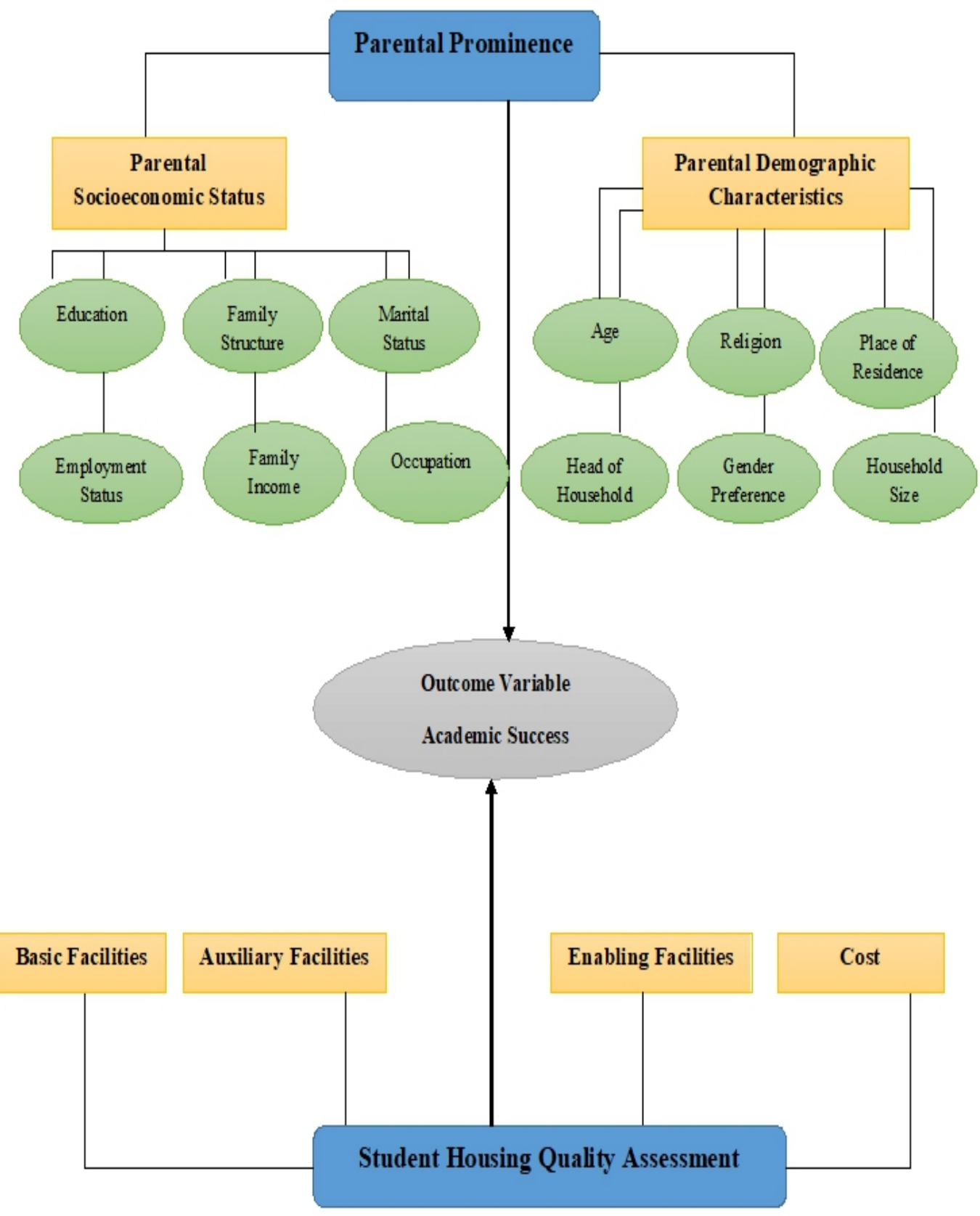

Figure 1: Conceptual model linking parental prominence and student housing to academic success 


\subsection{Methods}

\subsection{Research Design, Data Sources and Sample Design}

This study is a cross-sectional survey involving the usage of quantitative technique to investigate the influence of parental prominence and students' accommodation on academic success among students of selected public universities in Southwest Nigeria. Structured questionnaire was developed in line with the objectives of the study; and administered to final year undergraduate students of Obafemi Awolowo University, Ile-Ife, Osun State (OAU), Olabisi Onabanjo University, Ago-Iwoye, Ogun State (OOU) and Adekunle Ajasin University, Akungba, Ondo State (AAUA). The selection of respondents was purposive, and not based on age, mode of accommodation (on-campus and off-campus) or gender differentials. The total sample size was four hundred and twenty-six (426). The study adopted the multi-stage sampling method in the selection of study sample. At the first stage, the stratification of eligible population was done by the grouping of final year students into existing faculties in the study locations. The second stage followed with the grouping of final year students into various departments of learning; then followed by the purposive administering of the research instrument to identified population. One-hundred and fifty (150) copies questionnaire were administered to legible respondents in each of the three selected universities respectively. One hundred forty-eight (148) were copies of questionnaire retrieved from the OAU respondents; one hundred and fortytwo (142) from OOU respondents; and one-hundred and thirty-six (136) of the administered copies of questionnaire were retrieved from AAUA respondents. Therefore, the response rates were $98.7 \%$ in OAU, $94.7 \%$ and $90.7 \%$ in AAUA.

\subsection{Research Variables}

The response variable is academic success. The concept "academic success" as operationalised in this study is restricted to the cumulative grade points currently amassed by students. Thus, academic success was estimated based on the ordinal categorisation of academic grade points as approved by the Nigeria Universities Commission - ranging from the lowest $(1.0-1.49)$ to the highest $(4.5-5.0)$ obtainable grade points. Students, with at least 3.5 cumulative grade point were considered in this study to have attained outstanding academic success; those whose cumulative grade points ranged from 2.40 to 3.49 were regarded to have only attained a satisfactory academic success; while students whose cumulative grade points ranged from 1.0 to 2.39 were regarded in this study to have attained weak academic success. Students whose academic works are not graded on grade points were excluded from this study; hence, medical students that fall into this category were not inclusive in this study. The explanatory variables are parental prominence and 
student housing. Parental prominence was measured by parental socioeconomic characteristics (level of education, family structure, marital status, place of residence, family income - combined income, occupation type and employment status) and parental demographic characteristics (head of household, household size, age, religion affiliation, gender preference in relation to meeting child's education needs and place of residence).

Parental socioeconomic characteristics was further categorised into parental socioeconomic status (high socioeconomic status and low socioeconomic status) by adopting the component analysis technique. Parents (father and mother) with at least high school education, gainfully employed, living together in the same household and with at least US\$2.00 per each member of their household were classified as parents with high socioeconomic status irrespective of their family structure and other wise if these criteria were not met.. Respondent's parental prominence information was captured for each parent (mother/father) separately but jointly for family structure, marital status, religion and place of residence. Student housing was captured based on the quality and availability of basic facilities (bedroom facilities, bathroom facilities, electricity supply, water supply, toilet facilities and physical environment assessment), auxiliary facilities (buttery service, garage facility, common room, storage facilities and sporting facilities), enabling facilities (access to transportation, distance to lectures, kitchenette, reading/studying room, security, level of privacy and existing rules and regulations) and cost of facilities (accommodation fees, transportation fees, cost of supporting facilities - water, electricity, security). Student housing facilities were assessed regardless of mode of accommodation (off-campus/on-campus). The overall assessment of housing facilities was carried out in order to establish the quality of student housing in the three selected institutions.

\subsection{Data Analysis}

Data were collected through epi-data and exported to the SPSS (SPSS version 22 for Windows, SPSS Inc., Chicago IL). The collected data were sorted, cleaned, and then exported to Stata version 14. All statistical analysis were performed with the Stata version 14. The first level of analysis was performed using the appropriate descriptive statistics (percentage distribution, and mean/standard deviation scores for count variables). The overall weighted scores for the assessed student housing facility qualities were derived by the adoption of component score analysis. The one-way anova statistic was used to explain the level of contribution by each of the explanatory variables (Adjusted-R ${ }^{2}$ ) and the F-statistic was also calculated to establish the level of significance between the response and explanatory variables of the study. At the multivariate level of analysis, the rank-ordered logistic regression was employed. Thus, the rank ordered-logistic regression and ANOVA was 
applied using Stata 14. Respondents' current mode of accommodation (oncampus/off-campus hostel) was used as the "group variable for the rankordered analysis; the unit of analysis for each of the indicators used in this study was a final year student who was living with at least one of his/her biological parent. The confidence level for this study was fixed at 95\%. Therefore, the results of the study if found to be $<0.05$ was considered to be significantly associated.

\subsection{Results}

\subsubsection{Bio-data information of Respondents}

The results of the study by some basic personal information of the respondents as indicated in Table 1 showed that the mean age of the respondents was 23 years (23 \pm 1.92$)$. Also the results showed that at least twothirds (66.9\%) of the respondents were in age group 20-24 years; while nearly two-third (65.3\%) of the students were living in an off-campus accommodation. The distribution of the respondents by their institutions of learning showed that one (33.3\%) in every three of the respondents was a student of OOU, $34.7 \%$ were students of OAU and $31.9 \%$ were students of AAUA. The results further showed that about half (50.5\%) of the students harboured at least 3 squatters in their rooms currently. More so, the results showed that on the average 3 squatters $(3.21 \pm 0892)$ were harboured by a respondent in the current academic session. More than half $(55.4 \%)$ of the respondents spent at least a year as a squatter, with an average year spent as squatters approximately put at 2 years $(1.96 \pm 0.668)$. Results by respondents current faculty of learning showed that about a quarter $(24.7 \%)$ of the respondents were students in the faculties of Sciences and Environmental Design while nearly one-fifth (19.5\%) of the respondents were students in the faculties of Technology and Agriculture. Results by respondents current CGPA showed that very few of the students were in the lower $(2.1 \%)$ and upper (3.3\%) classifications. The results further show that about $47 \%$ of the respondents currently with a CGPA of more than 2.39 but less than 3.50 grade point. The mean grade point for the distribution was 3.34 on a scale of 5.0 (3.34 \pm 0.761$)$. In line with the aforementioned, less than half $(43.2 \%)$ of the respondents had an outstanding academic performance. The outcomes of the study also showed that more than two-third (69\%) of the respondents never received any financial supports in course of their studies. On the other hand, a quarter (25.4\%) of the respondents had benefited from bursaries while less than $4 \%$ had received scholarships or grants.

\subsubsection{Parental Prominence Characteristics of the Respondents}

The parental prominence characteristics by demographic variables as indicated in Table 2a showed that majority (82.2\%) of the respondents came 
from male headed households. Also, the outcomes of the study showed that more than four-fifth (82.4\%) of the respondents reported that their fathers gave equal right to their educational needs irrespective of their gender or sibling gender. Similarly, the results showed that majority (84.5\%) of the respondents reported that their mothers were not bias in giving educational supports to them or meeting their siblings educational needs irrespective of gender difference. Nearly three (59.6\%) in every five respondents were from Christian homes. The parental prominence distribution of the respondents by age show that father's and mother's age were 55 years $(55 \pm 6.712)$ and 52 years (52 \pm 6.552$)$ respectively. The results of the study by household size showed that a significant number (85.7\%) of the respondents were from large household with a minimum size of 5 and maximum of 9 household members.

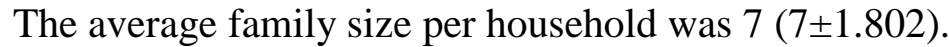

Also, the distribution of the respondents by their parental socioeconomic characteristics as indicated in Table $2 \mathrm{~b}$ showed that nearly three-quarters $(74.6 \%)$ of the respondents' parents were living in the urban settlements. About $40 \%$ of the respondents' fathers had no tertiary education with $6.6 \%$ having no form of formal education at all. Equally, about one-third (32.4\%) of the respondents' mothers had no tertiary education, $8.9 \%$ with no formal education at all. The results revealed that more of the respondents' fathers (84.5\%) were gainfully employed at the moment than their mothers (80.5\%). Results by family structure and parental marital status showed that slightly more than half (52.6\%) of the respondents from monogamous home, and $28.9 \%$ of the respondents were not living together with both of their parents $-8.9 \%$ from broken homes, 3.3\% have lost either of their parents and about $17 \%$ were living with their parents though not divorced, nevertheless not living under the same roof. The outcomes of the study by family earned income showed that less than a quarter (22.1\%) of the respondents came from a family with a monthly income of less than US\$300 per month, with twothirds (66.7\%) of the respondents' family combined (father and mother) standing in the range of US\$300 to US\$599 on monthly basis. We observed from the findings of our study that approximately $3 \%$ of the respondents' parents earned at least US\$900 on monthly basis while the average family income earned per month was put at US\$440.05 (440.05 \pm 229.797$)$. Considering the World Bank categorisation, at least one (11.7\%) in every ten of the respondents was from home living in abject poverty $(<$ US\$1 per household member) while approximately $45 \%$ of the respondents were from homes living below the poverty level ( $<$ US $\$ 2$ per household member). It was evident from the results of this study that the least income earned by a household was US\$0.60 while the highest income earned per household member was US $\$ 11.57$. Our results further show that the average income per household member was US\$2.15 (2.15 \pm 1.315$)$. It could also be deduced from 
the study's findings that about $60 \%$ of the parents of the respondents were of low socioeconomic status.

\subsubsection{Assessments of Students Housing Quality}

The distribution of the respondents by bedroom facilities as indicated in Table 3 showed that two-thirds (66.7\%) of the students reported that their bedroom facilities were functional but inadequately provided; and one-third (33.1\%) lamented that their bathroom facilities were not only inadequate but also not functioning well. In terms of electricity supply, $6.8 \%$ of the students reported that they had no access to public electricity supply in their accommodation while less than $20 \%$ of the students had access to adequate and functional power supply. The results on provision of basic facilities also show that about $30 \%$ of the students had no access to adequate and functional piped-borne water in their hostels and $5.9 \%$ of the students had no access to piped-borne water supply at all. Only, $8.9 \%$ of the respondents had access to adequate and functional toilet facilities with $2.1 \%$ of the students having no access to bathroom facilities at all in their hostels. The results by the aggregate assessment of basic facilities in student hostels showed that less than one-tenth (7\%) of the students were provided with adequate and functional basic facilities across the selected higher institutions of learning. Results by assessment of student housing enabling facilities showed that about $60 \%$ of the respondents had no access to functional and adequate transportation and more than half $(51.9 \%)$ were not provided with adequate and functional reading room in their hostels. Furthermore, the results showed that only $2.6 \%$ of the respondents had access to kitchenette facilities in their hostels. About one-quarter (25.6\%) of the students reported that they were not secured in the hostels and approximately $2 \%$ admitted that the existing rules and regulations in their hostels were adequate and functional. Results by aggregate assessment of enabling facilities showed that significant number (47.4\%) of the students had no access to functional and adequate enabling housing facilities in their various hostels.

As indicated in Table 3, the distribution of the respondents by assessment of housing auxiliary facility quality showed that more than a onequarter $(27.9 \%)$ of the students were residence of accommodations with no garage facility. About half $(52.8 \%)$ of the students were provided with functional but inadequate buttery facilities. The results further showed that less than $1.5 \%$ of the students had access to adequate and functional common rooms in their hostels and approximately one-quarter of the students had no access to sporting facilities in their hostels. The outcomes of the study showed that an insignificant (2.1\%) proportion of the students were provided with adequate and functional storage facility in their hostels. The aggregate score by assessment of student housing auxiliary facilities shows that more than half 
(52.6\%) of the respondents had no access to adequate and functional auxiliary facility in their hostels. Results by assessment of cost of accommodation showed that about two-thirds (63.9\%) of the students were of the opinion that the cost of student hostels was unaffordable though admitted that student accommodation was adequately provided and $6.6 \%$ of the students admitted that the cost of transportation was adequate and that transport service in their schools was adequate. The results also showed that more than one-quarter (28.2\%) of the students stated that the cost of enabling facilities in their institution was affordable but insisted that enabling facilities were not adequately provided in their hostels. The outcomes of the study by the aggregate assessment of student accommodation showed that about 30\% of the students could not afford the cost of accommodation. Results by overall assessment of students housing quality showed that more than half (52.6\%) of the students complained of the poor quality of their hostel while less than $3 \%$ admitted that the quality of their current accommodation was good.

\subsubsection{Results of Analysis of Variance showing the Relationship between Student Housing Quality and Parental Socioeconomic Status/Financial Supports Received by Students}

As indicated in Table 4, the outcomes of the analysis of variance showed that there was a significant relationship between student housing auxiliary facility quality and academic success (f-test $=4.33$; $\mathrm{p}=0.013$ ). Also, the results showed that academic success was significantly influenced by cost of accommodation ( $\mathrm{f}$-test $=5.06$; $\mathrm{p}=0.007$ ). Furthermore, the results showed that the overall assessment of housing quality and academic success were significantly associated (f-test $=4.73 ; \mathrm{p}=0.012$ ). Similarly, financial supports and academic success were found to be significantly associated (f-test $=9.52$; $\mathrm{p}=0.000$ ). More so, the outcomes of the study showed that student housing quality and financial supports received by students contributed about $9 \%$ to their academic success.

\subsubsection{Results of Rank-Ordered Logistic Regression Showing Association between Parental Prominence/Student Housing Quality and Academic Success}

As shown in Table 5 below, the results of the likelihood ratio chisquare of 62.54 with a p-value of 0.000 is an indication that our model as a whole is statistically significant as compared to the null model with no predictor. The results of the study further showed that bedroom $(\mathrm{z}=2.34$; $\mathrm{p}=0.019)$ and bathroom $(\mathrm{z}=2.23 ; \mathrm{p}=0.026)$ facilities were statistically significant with academic performance. Electricity supply was found to be inversely and significantly associated with academic success $(\mathrm{z}=-2.74$; $\mathrm{p}=0.002$ ). From these results, we expect a 0.43 increase in the log odds of 
academic success where students were provided with adequate and functional bedroom facilities in their hostels, controlling for other variables in the model. Also, we expect a 0.37 increase in the log odds of academic success where students were provided with adequate and functional bathroom facilities in their hostels, controlling for other variables in the model. Likewise, we expect a 0.13 increase in the log odds of academic success where students were provided with constant and adequate power supply in their hostels, controlling for other variables in the model. More so, the results show that distance to lectures and academic success were significantly associated $(\mathrm{z}=-2.21$; $\mathrm{p}=0.022)$. The results likewise showed that reading $\operatorname{room}(\mathrm{z}=-2.42 ; \mathrm{p}=0.016)$, garage $(\mathrm{z}=-2.68 ; \mathrm{p}=0.007)$ and common $\operatorname{room}(\mathrm{z}=-2.15$; $\mathrm{p}=0.031)$ were inversely and statistically significant with academic success. It was evident from the study that sporting facilities and academic success were significantly associated ( $\mathrm{z}=3.58 ; \mathrm{p}=0.000)$; the result indicates that we expect 0.50 increase in the log odds of academic success where students were provided with adequate and functional sporting facilities in their hostels, controlling for other variables in the model. Cost of accommodation was found to be significantly associated with academic success $(\mathrm{z}=-2.61 ; \mathrm{p}=0.009)$. Also, the results show that aggregate enabling facilities and academic success were statistically significant $(\mathrm{z}=2.55 ; \mathrm{p}=0.011)$. Thus, we expect a 0.46 increase in the log odds of academic success where students were provided with adequate and functional basic facilities in their hostels, controlling for other variables in the model.

The results of the study by parental prominence and academic success as indicated in Table 5 showed that there was an inverse and significant association between father's gender preference towards education and academic success $(\mathrm{z}=-2.08 ; \mathrm{p}=0.037)$. Also, mother's employment status was found to be significant associated with academic success ( $\mathrm{z}=1.94 ; \mathrm{p}=0.039)$. Mother's occupation type and academic success were found to be significantly associated $(\mathrm{z}=2.10 ; \mathrm{p}=0.036)$. Likewise, marital status was established in this study to be inversely and statistically significant with academic success $(\mathrm{z}=-$ 2.33; $\mathrm{p}=0.023)$. The results also showed that we expect a 0.46 in the log odds of academic success where a student's mother was gainfully employed controlling for other variables in the model.

Table 1: Percent Distribution of Respondents by Bio-data Profile

\begin{tabular}{|l|c|c|}
\hline Variable & \multicolumn{2}{|c|}{ Students' Bio-Data Profile } \\
\cline { 2 - 3 } & \multicolumn{2}{|c|}{ Frequency (N=426) } \\
\hline Names of Selected Universities & 136 & 31.9 \\
\hline Adekunle Ajasin University (AAUA) & 148 & 34.7 \\
\hline Obafemi Awolowo University (OAU) & 142 & 33.3 \\
\hline Olabisi Onabanjo University (OOU) & 120 & 28.2 \\
\hline Current Faculty in Institution of Learning & \multicolumn{2}{|c|}{} \\
\hline Arts/Education & \multicolumn{2}{|c|}{} \\
\hline
\end{tabular}




\begin{tabular}{|c|c|c|}
\hline Management/Social Sciences & 118 & 27.7 \\
\hline Sciences/Environmental Design & 105 & 24.7 \\
\hline Technology/Agriculture & 83 & 19.5 \\
\hline \multicolumn{3}{|l|}{ Age } \\
\hline$<20$ years & 43 & 10.1 \\
\hline $20-24$ years & 285 & 66.9 \\
\hline $25-29$ years & 75 & 17.6 \\
\hline 30 years $\&$ above & 23 & 5.4 \\
\hline Mean age \& $S D(\min =18 ; \max =36)$ & $23 \pm 3.192$ & \\
\hline \multicolumn{3}{|l|}{ Gender } \\
\hline Male & 222 & 52.1 \\
\hline Female & 204 & 47.9 \\
\hline \multicolumn{3}{|l|}{ Mode of Accommodation in the current Session } \\
\hline School hostel (on-campus) & 148 & 34.7 \\
\hline Private hostel (off-campus) & 278 & 65.3 \\
\hline \multicolumn{3}{|l|}{ Number of Squatters in your Current Room } \\
\hline 0 & 10 & 2.4 \\
\hline 1 & 103 & 24.2 \\
\hline 2 & 98 & 23.0 \\
\hline 3 or more & 215 & 50.5 \\
\hline Mean \& SD for squatters per room $(\min =0 ; \max =4)$ & \multicolumn{2}{|c|}{$3.21 \pm 0.892$} \\
\hline \multicolumn{3}{|l|}{ Years spent as a Squatter } \\
\hline$<1$ year & 103 & 24.2 \\
\hline 1 years & 236 & 55.4 \\
\hline 2 years \& more & 87 & 20.4 \\
\hline Mean \& SD of years spent as squatters $(\min =1 ; \max =3)$ & \multicolumn{2}{|c|}{$1.96 \pm 0.668$} \\
\hline \multicolumn{3}{|l|}{ Current CGPA } \\
\hline$<1.5$ & 9 & 2.1 \\
\hline $1.5-2.39$ & 34 & 7.9 \\
\hline $2.4-3.49$ & 199 & 46.7 \\
\hline 3.5-4.49 & 170 & 39.9 \\
\hline 4.5 \& above & 14 & 3.3 \\
\hline Mean \& SD scores of CGPA $(\min =1 ; \max =5)$ & \multicolumn{2}{|c|}{$3.34 \pm 0.761$} \\
\hline \multicolumn{3}{|l|}{ Academic Success } \\
\hline Outstanding & \multicolumn{2}{|c|}{$184(43.2)$} \\
\hline Weak & \multicolumn{2}{|c|}{$242(56.8)$} \\
\hline \multicolumn{3}{|l|}{ Financial Supports (Scholarship/Grant/ Bursary) } \\
\hline Received no supports & 294 & 69.0 \\
\hline Received bursary & 108 & 25.4 \\
\hline Received scholarship/grants & 16 & 3.8 \\
\hline Received bursary and scholarship/grant & 8 & 1.9 \\
\hline
\end{tabular}

Source: Authors’ Survey Report 2019; Note (CGPA= Cumulative Grade Points Average) 
Table 2a: Percent Distribution of Respondents by Parental Prominence Characteristics (Demographic Variables)

\begin{tabular}{|c|c|c|}
\hline \multirow[t]{2}{*}{ Variable } & \multicolumn{2}{|c|}{ Parental Selected Demographic Characteristics } \\
\hline & Frequency $(\mathrm{N}=426)$ & $\%$ \\
\hline \multicolumn{3}{|l|}{ Head of Household } \\
\hline Male & 350 & 82.2 \\
\hline female & 76 & 17.8 \\
\hline \multicolumn{3}{|c|}{ Father's Gender Preference towards Child's Education } \\
\hline Preference given to male child & 59 & 13.9 \\
\hline Preference given to female child & 16 & 3.8 \\
\hline Equal right irrespective of gender difference & 351 & 82.4 \\
\hline \multicolumn{3}{|c|}{ Mother's Gender Preference towards Child's Education } \\
\hline Preference given to male child & 40 & 9.4 \\
\hline Preference given to female child & 27 & 6.3 \\
\hline Equal right irrespective of gender difference & 359 & 84.3 \\
\hline \multicolumn{3}{|l|}{ Religious Affiliation (Head of Household) } \\
\hline Christianity & 254 & 59.6 \\
\hline Islam & 150 & 35.2 \\
\hline Traditional/Others & 22 & 5.2 \\
\hline \multicolumn{3}{|l|}{ Father's Age } \\
\hline $36-45$ years & 17 & 4.0 \\
\hline $46-55$ years & 206 & 48.4 \\
\hline $56-65$ years & 169 & 39.7 \\
\hline$>65$ years & 34 & 8.0 \\
\hline Mean age of fathers \& SD ( $\min =44 ; \max =72)$ & \multicolumn{2}{|c|}{$55 \pm 6.712$} \\
\hline \multicolumn{3}{|l|}{ Mother's Age } \\
\hline $36-45$ years & 95 & 22.3 \\
\hline 46-55 years & 212 & 49.8 \\
\hline $56-65$ years & 114 & 26.8 \\
\hline$>65$ years & 5 & 1.2 \\
\hline Mean age of mothers \& SD ( $\min =37 ; \max =68)$ & \multicolumn{2}{|c|}{$52 \pm 6.552$} \\
\hline \multicolumn{3}{|l|}{ Household Size } \\
\hline$<5$ household members & 22 & 5.2 \\
\hline 5-9 household members & 365 & 85.7 \\
\hline 10 or more & 39 & 9.2 \\
\hline Mean household size \& SD (min=3; $\max =13)$ & \multicolumn{2}{|c|}{$7 \pm 1.802$} \\
\hline
\end{tabular}

Source: Authors' Survey Report 2019 
Table 2b: Percent Distribution of Respondents by Parental Prominence Characteristics (Socioeconomic Variables)

\begin{tabular}{|c|c|c|}
\hline \multirow[t]{2}{*}{ Variable } & \multicolumn{2}{|c|}{ Parental Socioeconomic Characteristics } \\
\hline & Frequency $(\mathrm{N}=426)$ & $\%$ \\
\hline \multicolumn{3}{|l|}{ Place of Residence (Head of Household) } \\
\hline Rural & 108 & 25.4 \\
\hline Urban & 318 & 74.6 \\
\hline \multicolumn{3}{|l|}{ Father's Level of Education } \\
\hline No formal education & 28 & 6.6 \\
\hline Primary & 41 & 9.6 \\
\hline Secondary & 189 & 44.4 \\
\hline Tertiary & 168 & 39.4 \\
\hline \multicolumn{3}{|l|}{ Mother's Level of Education } \\
\hline No formal education & 36 & 8.9 \\
\hline Primary & 8 & 1.9 \\
\hline Secondary & 242 & 56.8 \\
\hline Tertiary & 138 & 32.4 \\
\hline \multicolumn{3}{|l|}{ Father's Current Employment Status } \\
\hline Employed & 359 & 84.3 \\
\hline Unemployed & 67 & 15.7 \\
\hline \multicolumn{3}{|l|}{ Mother's Current Employment Status } \\
\hline Employed & 343 & 80.5 \\
\hline Unemployed & 83 & 19.5 \\
\hline \multicolumn{3}{|l|}{ Family Structure } \\
\hline Monogamy & 224 & 52.6 \\
\hline Polygamy & 202 & 47.4 \\
\hline \multicolumn{3}{|l|}{ Parental Marital Status } \\
\hline Married (living together) & 303 & 71.1 \\
\hline Married (living separately) & 71 & 16.7 \\
\hline Divorced (single parenthood) & 38 & 8.9 \\
\hline At most one parent is not alive & 14 & 3.3 \\
\hline \multicolumn{3}{|l|}{ Family income (monthly) } \\
\hline$<\mathrm{US} \$ 300$ & 94 & 22.1 \\
\hline US\$300-US\$599 & 284 & 66.7 \\
\hline US\$600-US\$899 & 35 & 8.2 \\
\hline US\$900 \& above & 13 & 3.1 \\
\hline $\begin{array}{lcccc}\begin{array}{l}\text { Mean } \\
\max =U S \$ 2083.33)\end{array} & \text { income } \$ & \text { SD } & (\min =U S \$ 166.67 ;\end{array}$ & $440.05 \pm 2$ & \\
\hline \multicolumn{3}{|l|}{ Income Received by each Household Member } \\
\hline$<$ US\$1 & 50 & 11.7 \\
\hline US\$1.99-US\$1.99 & 191 & 44.8 \\
\hline US\$2 or more & 185 & 43.4 \\
\hline $\begin{array}{l}\text { Mean income received by each household member \& SD } \\
(\min =U S \$ 0.60 ; \max =U S \$ 11.57)\end{array}$ & \multicolumn{2}{|c|}{$2.15 \pm 1.315$} \\
\hline \multicolumn{3}{|l|}{ Parental Socioeconomic Status } \\
\hline Low & 256 & 60.1 \\
\hline High & 170 & 39.9 \\
\hline
\end{tabular}

Source: Authors' Survey Report 2019 
Table 3: Percent Distribution of Respondents by Assessment of Students' Housing Quality

\begin{tabular}{|c|c|c|c|c|}
\hline \multirow{2}{*}{$\begin{array}{l}\text { Variable } \\
\text { Basic facilities }\end{array}$} & \multicolumn{4}{|c|}{ Assessment of Student Housing Basic Facility Quality $(\mathrm{N}=426)$} \\
\hline & $\begin{array}{c}\text { Adequate/ } \\
\text { Functional } \\
(\%)\end{array}$ & $\begin{array}{c}\text { Functional/ } \\
\text { Inadequate (\%) }\end{array}$ & $\begin{array}{c}\text { Inadequate/ } \\
\text { Not-functional (\%) }\end{array}$ & $\begin{array}{c}\text { Not Available } \\
(\%)\end{array}$ \\
\hline Bedroom facilities & $50(11.7)$ & 284(66.7) & 90(21.1) & $2(0.5)$ \\
\hline Bathroom facilities & $32(7.5)$ & 244(57.3) & 141(33.1) & $9(2.1)$ \\
\hline Electricity supply (public) & $75(17.6)$ & 196(46.0) & $126(29.6)$ & 29(6.8) \\
\hline Piped borne water & $27(6.4)$ & 247(57.9) & $127(29.8)$ & $25(5.9)$ \\
\hline Toilet facility & $38(8.9)$ & 226(53.1) & $162(38.0)$ & $0(0.0)$ \\
\hline Physical environment & $32(7.5)$ & $235(55.2)$ & 159(37.3) & $0(0.0)$ \\
\hline \multirow[t]{2}{*}{ Variable } & \multicolumn{4}{|c|}{ Aggregate Assessment of Student Housing Basic Facility Quality } \\
\hline & $\begin{array}{c}\text { Functional/ } \\
\text { Adequate (\%) }\end{array}$ & $\begin{array}{c}\text { Functional/ } \\
\text { Inadequate (\%) }\end{array}$ & \multicolumn{2}{|c|}{$\begin{array}{c}\text { Inadequate/Not Functional } \\
(\%)\end{array}$} \\
\hline Basic facility Quality & $30(7.0)$ & $166(39.0)$ & \multicolumn{2}{|c|}{$230(54.0)$} \\
\hline Variable & \multicolumn{4}{|c|}{ Assessment of Student Housing Enabling Facility Quality } \\
\hline Enabling Facilities & $\begin{array}{c}\text { Adequate/ } \\
\text { Functional } \\
\text { (\%) } \\
\end{array}$ & $\begin{array}{c}\text { Functional/ } \\
\text { Inadequate (\%) }\end{array}$ & $\begin{array}{c}\text { Inadequate/ Not- } \\
\text { functional (\%) }\end{array}$ & $\begin{array}{c}\text { Not Available } \\
\text { (\%) }\end{array}$ \\
\hline Transportation (campus shuttle) & $27(6.3)$ & 253(59.39) & 131(30.8) & $15(3.5)$ \\
\hline Kitchenette & $11(2.6)$ & $263(61.7)$ & 104(24.4) & $48(11.3)$ \\
\hline Reading room & 16(3.8) & 221(51.9) & $129(30.3)$ & $60(14.1)$ \\
\hline Security & $27(6.3)$ & $270(63.4)$ & $109(25.6)$ & $20(4.7)$ \\
\hline Existing Rules and Regulations & $9(2.1)$ & 289(67.8) & $95(22.3)$ & $33(7.8)$ \\
\hline Variable & \multicolumn{2}{|c|}{ Near/Not a Problem } & Far & Very far \\
\hline Distance to Lectures & \multicolumn{2}{|c|}{$19(4.5)$} & $265(62.2)$ & $142(33.3)$ \\
\hline Variable & Had Privacy & Had Privacy & \multicolumn{2}{|c|}{ Had Privacy } \\
\hline Access to Privacy in Hostel & $33(7.8)$ & 263(61.7) & \multicolumn{2}{|c|}{$130(30.5)$} \\
\hline \multirow[t]{2}{*}{ Variable } & \multicolumn{4}{|c|}{ Aggregate Assessment of Student Housing Enabling Facility Quality } \\
\hline & $\begin{array}{c}\text { Functional/ } \\
\text { Adequate (\%) }\end{array}$ & $\begin{array}{c}\text { Functional/ } \\
\text { Inadequate (\%) }\end{array}$ & \multicolumn{2}{|c|}{$\begin{array}{c}\text { Inadequate/Not Functional } \\
(\%)\end{array}$} \\
\hline Enabling facility Quality & $38(8.9)$ & $186(43.7)$ & $202(4$ & \\
\hline Variable & \multicolumn{4}{|c|}{ Assessment of Student Housing Auxiliary Facility Quality } \\
\hline Housing Auxiliary Facilities & $\begin{array}{c}\text { Adequate/ } \\
\text { Functional } \\
(\%) \\
\end{array}$ & $\begin{array}{c}\text { Functional/ } \\
\text { Inadequate (\%) }\end{array}$ & $\begin{array}{c}\text { Inadequate/ Not- } \\
\text { functional (\%) }\end{array}$ & $\begin{array}{c}\text { Not Available } \\
(\%)\end{array}$ \\
\hline Garage & $5(1.2)$ & 198(46.5) & $104(24.4)$ & $119(27.9)$ \\
\hline Buttery & $7(1.5)$ & $225(52.8)$ & $117(27.5)$ & $77(18.1)$ \\
\hline Common room & $6(1.4)$ & $180(42.3)$ & 138(32.4) & $102(23.9)$ \\
\hline Sporting Facility & $9(2.1)$ & $165(38.7)$ & $140(32.9)$ & 112(26.3) \\
\hline Storage facility & $9(2.1)$ & $172(40.4)$ & $154(36.2)$ & $91(21.4)$ \\
\hline \multirow[t]{2}{*}{ Variable } & \multicolumn{4}{|c|}{ Aggregate Assessment of Student Housing Auxiliary Facility Quality } \\
\hline & $\begin{array}{c}\text { Functional/ } \\
\text { Adequate (\%) }\end{array}$ & $\begin{array}{c}\text { Functional/ } \\
\text { Inadequate (\%) }\end{array}$ & \multicolumn{2}{|c|}{$\begin{array}{c}\text { Inadequate/Not Functional } \\
(\%)\end{array}$} \\
\hline Auxiliary Facility Quality & $6(1.4)$ & $196(46.0)$ & $224(5$ & \\
\hline Variable & \multicolumn{4}{|c|}{ Assessment of Cost of Student Accommodation } \\
\hline Cost & $\begin{array}{c}\text { Affordable/ } \\
\text { Adequate (\%) }\end{array}$ & $\begin{array}{l}\text { Unaffordable/ } \\
\text { Adequate (\%) }\end{array}$ & $\begin{array}{c}\text { Affordable/ } \\
\text { Inadequate (\%) }\end{array}$ & $\begin{array}{c}\text { Unaffordable/ } \\
\text { Inadequate (\%) }\end{array}$ \\
\hline
\end{tabular}




\begin{tabular}{|c|c|c|c|c|}
\hline Cost of Accommodation & $38(8.9)$ & 272(63.9) & 105(24.7) & 11(2.6) \\
\hline Cost of Transportation & $28(6.6)$ & $248(58.2)$ & 136(31.9) & 14(3.3) \\
\hline Cost of Enabling facilities & $48(11.3)$ & $240(56.3)$ & $120(28.2)$ & $18(4.2)$ \\
\hline \multirow[t]{2}{*}{ Variable } & \multicolumn{4}{|c|}{ Aggregate Assessment of Cost of Student Accommodation } \\
\hline & \multicolumn{2}{|c|}{ Affordable (\%) } & \multicolumn{2}{|c|}{ Unaffordable (\%) } \\
\hline Cost of Accommodation & \multicolumn{2}{|c|}{$302(70.9)$} & \multicolumn{2}{|c|}{$124(29.1)$} \\
\hline \multirow[t]{2}{*}{ Variable } & \multicolumn{4}{|c|}{ Overall Assessment of Student Housing Quality } \\
\hline & Good (\%) & Fair (\%) & & \\
\hline Housing Quality & $12(2.8)$ & $190(44.6)$ & & \\
\hline
\end{tabular}

Source: Authors' Survey Report 2019; Physical environment (e.g. drainage \& waste disposal)

Table 4: Results of the One-way ANOVA between Academic Success and Student Housing Quality/Parental Socioeconomic Status/Financial Supports Received by Students

\begin{tabular}{|c|c|c|c|c|c|}
\hline Source & Partial SS & df & MS & F-statistic & Prob. $>$ F \\
\hline Model & 28.619 & 15 & 1.908 & 3.60 & 0.000 \\
\hline Basic Facility & 1.764 & 2 & 0.882 & 2.46 & 0.086 \\
\hline Enabling Facility & 2.914 & 2 & 1.457 & 2.75 & 0.065 \\
\hline Auxiliary Facility & 4.594 & 2 & 2.297 & 4.33 & $0.013^{*}$ \\
\hline Cost of Accommodation & 5.367 & 2 & 2.684 & 5.06 & $0.007 * *$ \\
\hline Overall Assessment of Housing Quality & 2.434 & 2 & 1.217 & 4.73 & $0.012 *$ \\
\hline Parental Socioeconomic Status & 0.131 & 1 & 0.131 & 0.25 & 0.619 \\
\hline Financial Supports & 15.125 & 3 & 5.048 & 9.52 & $0.000 * * *$ \\
\hline Residual & 217.344 & 410 & 0.530 & & \\
\hline Total & 245.962 & 425 & 0.579 & & \\
\hline Number of Obs & 426 & & & & \\
\hline Adjusted -R ${ }^{2}$ & & & 0.0 & & \\
\hline
\end{tabular}

Note:*Significant at $\mathrm{p}<0.05$, **Significant at $\mathrm{p}<0.01$, ***Significant at $\mathrm{p}<0.001$; Obs $=$ observation;

$\mathrm{df}=$ degree of freedom; $\mathrm{SS}=$ sum of square; $\mathrm{MS}=$ mean of sums

Table 5: Rank-ordered Logistic Regression Results Showing Association between Parental Prominence/Student Housing Quality and Academic Success

\begin{tabular}{|c|c|c|c|c|c|}
\hline Variable & Coefficient & Std. Err. & $\mathbf{Z}$ & $\mathbf{P}>|\mathbf{z}|$ & 95\% C.I. \\
\hline \multicolumn{6}{|l|}{ Housing Facilities } \\
\hline Bedroom & 0.429 & 0.183 & 2.34 & 0.019* & $\begin{array}{l}0.070 \\
0.789\end{array}$ \\
\hline Bathroom & 0.368 & 0.165 & 2.23 & $0.026^{*}$ & $\begin{array}{l}0.045 \\
0.691\end{array}$ \\
\hline Electricity supply & 0.230 & 0.132 & -2.74 & $0.002 * *$ & $\begin{array}{c}-0.030 \\
0.489\end{array}$ \\
\hline
\end{tabular}




\begin{tabular}{|c|c|c|c|c|c|}
\hline Water supply & -0.145 & 0.170 & -0.85 & 0.393 & $\begin{array}{l}-0.478 \\
0.187\end{array}$ \\
\hline Toilet & -0.223 & 0.165 & -1.36 & 0.175 & $\begin{array}{c}-0.546 \\
0.099 \\
\end{array}$ \\
\hline Physical environment & -0.223 & 0.194 & -0.61 & 0.542 & $\begin{array}{c}-0.499 \\
0.262\end{array}$ \\
\hline Transportation & 0.069 & 0.157 & 0.44 & 0.658 & $\begin{array}{c}-0.239 \\
0.378\end{array}$ \\
\hline Distance to lectures & -0.298 & 0.171 & -2.31 & $0.022^{*}$ & $\begin{array}{c}-0.633 \\
0.038 \\
\end{array}$ \\
\hline Kitchenette & -0.053 & 0.126 & -0.42 & 0.673 & $\begin{array}{c}-0.300 \\
0.194 \\
\end{array}$ \\
\hline Reading room & -0.300 & 0.124 & -2.42 & $0.016^{*}$ & $\begin{array}{c}-0.543- \\
0.570\end{array}$ \\
\hline Privacy & -0.014 & 0.157 & -0.09 & 0.928 & $\begin{array}{r}-0.322 \\
0.294 \\
\end{array}$ \\
\hline Security & 0.022 & 0.148 & 0.15 & 0.882 & $\begin{array}{c}-0.268 \\
0.311 \\
\end{array}$ \\
\hline Rules and Regulations & 0.040 & 0.148 & 0.27 & 0.789 & $\begin{array}{c}-0.251 \\
0.331 \\
\end{array}$ \\
\hline Garage & -0.336 & 0.125 & -2.68 & $0.007 * *$ & $\begin{array}{c}-0.581- \\
0.090 \\
\end{array}$ \\
\hline Buttery & 0.172 & 0.151 & 1.14 & 0.254 & $\begin{array}{c}-0.124 \\
0.468\end{array}$ \\
\hline Common room & -0.370 & 0.172 & -2.15 & $0.031 *$ & $\begin{array}{c}-0.706- \\
0.033 \\
\end{array}$ \\
\hline Sporting facilities & 0.495 & 0.138 & 3.58 & $0.000^{* * *}$ & $\begin{array}{c}-0.224 \\
0.767 \\
\end{array}$ \\
\hline Storage & 0.042 & 0.130 & 0.32 & 0.745 & $\begin{array}{c}-0.213 \\
0.297 \\
\end{array}$ \\
\hline Cost of accommodation & -0.376 & 0.144 & -2.61 & $0.009 * *$ & $\begin{array}{l}-0.658- \\
0.094 \\
\end{array}$ \\
\hline Cost of transportation & 0.138 & 0.148 & 0.94 & 0.350 & $\begin{array}{c}-0.151 \\
0.428 \\
\end{array}$ \\
\hline $\begin{array}{l}\text { Cost of enabling facilities (water, } \\
\text { electricity, etc.) }\end{array}$ & 0.109 & 0.112 & 0.97 & 0.332 & $\begin{array}{c}-0.111 \\
0.328 \\
\end{array}$ \\
\hline Aggregate basic facilities & -0.254 & 0.160 & -1.58 & 0.113 & $\begin{array}{c}-0.569 \\
0.060 \\
\end{array}$ \\
\hline Aggregate enabling facilities & 0.176 & 0.168 & 1.05 & 0.295 & $\begin{array}{c}-0.153 \\
0.506\end{array}$ \\
\hline Aggregate auxiliary facilities & 0.461 & 0.180 & 2.55 & $0.011^{*}$ & $0.107 \quad 0.814$ \\
\hline Aggregate cost & 0.020 & 0.144 & 0.14 & 0.892 & $\begin{array}{c}-0.263 \\
0.302 \\
\end{array}$ \\
\hline Overall housing quality & -0.026 & 0.290 & -0.09 & 0.928 & $\begin{array}{c}-0.595 \\
0.542 \\
\end{array}$ \\
\hline \multicolumn{6}{|l|}{ Parental prominence } \\
\hline Head of household & -0.061 & 0.200 & -0.30 & 0.762 & $\begin{array}{c}-0.452 \\
0.331\end{array}$ \\
\hline
\end{tabular}




\begin{tabular}{|c|c|c|c|c|c|}
\hline Family structure & -0.148 & 0.242 & -0.61 & 0.541 & $\begin{array}{l}-0.623 \\
0.327 \\
\end{array}$ \\
\hline Household size & 0.002 & 0.066 & 0.03 & 0.975 & $\begin{array}{c}-0.126 \\
0.131 \\
\end{array}$ \\
\hline Father's gender preference & -0.217 & 0.109 & -2.08 & $0.037 *$ & $\begin{array}{c}-0.431- \\
0.003\end{array}$ \\
\hline Father's educational attainment & 0.121 & 0.117 & 1.03 & 0.301 & $\begin{array}{c}-0.108 \\
0.350 \\
\end{array}$ \\
\hline Mother's educational attainment & -0.062 & 0.115 & -0.54 & 0.587 & $\begin{array}{c}-0.288 \\
0.163 \\
\end{array}$ \\
\hline Father's employment status & 0.278 & 0.325 & 0.86 & 0.392 & $\begin{array}{c}-0.358 \\
0.915 \\
\end{array}$ \\
\hline Mother's employment status & 0.460 & 0.262 & 1.94 & $0.039 *$ & $\begin{array}{l}-0.053 \\
0.973 \\
\end{array}$ \\
\hline Father's occupation type & 0.029 & 0.068 & 0.43 & 0.671 & $\begin{array}{c}-0.104 \\
0.161 \\
\end{array}$ \\
\hline Mother's occupation type & 0.125 & 0.059 & 2.10 & $0.036 *$ & $0.008 \quad 0.242$ \\
\hline Marital status & -0.235 & 0.101 & -2.33 & $0.020 *$ & $\begin{array}{c}-0.433- \\
0.038 \\
\end{array}$ \\
\hline Parental socioeconomic status & -0.09 & 0.220 & -0.39 & 0.695 & $\begin{array}{c}-0.518 \\
0.346 \\
\end{array}$ \\
\hline \multicolumn{6}{|c|}{ Log Likelihood = -440.339 } \\
\hline \multicolumn{6}{|c|}{ LRC (Chi 2) $=62.54$} \\
\hline \multicolumn{6}{|c|}{ Prob. $>$ Chi $2=0.000$} \\
\hline \multicolumn{6}{|c|}{ No of Observation $=426$} \\
\hline \multicolumn{6}{|c|}{ No of group $=2$} \\
\hline
\end{tabular}

Note:*Significant at $\mathrm{p}<0.05$, ${ }^{* *}$ Significant at $\mathrm{p}<0.01,{ }^{* * *}$ Significant at $\mathrm{p}<0.001$

\subsection{Discussion of Findings}

The predictive factors of academic success, particularly among undergraduates across public universities in Nigeria range from teachers' quality, attitude towards work, student hostel, students' attitude towards their studies, extent of government funding to environmental but not limited to societal impediments. Evidence from our study clearly revealed that parental demographic and socioeconomic status have significant influence on undergraduates' academic success in southwest universities. We discovered that the extent of academic success attained by undergraduate students in southwest public universities in Nigeria to a very large extent was influenced by the employment status of their mothers. In course of this study, we also discovered that the parental marital status of undergraduate students in southwest universities did influence the level of academic success attained by these students. We also observed from the findings of our study that father's gender preference had significant influence on student academic success. Our study's findings were partially in line Alokan, Osakinle \& Onijingin (2013) that identified parental educational background along with other key factors 
are certainly predictors of students' academic performance. Also, in line with our study's outcome, Olatunji et al., (2016) identified parental supports in kinds and cash as one of the factors influencing undergraduate students' academic performance, though in construction related disciplines. More so, we discovered that while one (20.4\%) in every five of the respondents had lived at least a year as a squatter, more than half (56.8\%) of the respondents did not attain an outstanding result in their studies. Our findings here could be allied to the findings by Oyetunji \& Abidoye (2016) who argued that the type of accommodation that students of tertiary institution lived in was majorly determined by how much financial supports they got, as well as the place of location of the institution and cost of acquiring such accommodation.

Our findings also established the existence of direct and significant link between academic success and financial supports that were made available to undergraduate students in the universities. Likewise, our findings were in support of Dervarics \& O'Brien (2011) that maintained that the contributions of parents could not be discarded in view of how success a student could attain in his or her academic endeavour. It is evidence from our study outcomes that type and quality of student housing had influence on their attainment of academic success. We discovered that more than half of the students (54\%) neither had access to functional basic student housing facility nor adequately provided with these amenities. It was also revealing that less than $9 \%$ of the respondents was adequately provided with functional housing enabling facilities across their various hostels. It was also evident from our studies that less than $2 \%$ of the respondents were provided with adequate and functional housing supportive facilities while about $30 \%$ of the students could not afford housing costs. In line with these, we discovered that attainment of academic success among undergraduate students was influenced by the extent and quality of housing auxiliary facilities that were made available to them. The findings of our study established a line of significant association between cost of accommodation and attainment of academic success by the respondents. More so, we discovered that the quality of student housing quality played a significant role in the attainment of academic success by undergraduate students in OAU, AAUA and OOU. Our findings were in affirmation with Owolabl (2015) and Oluwafemi (2015) that maintained that student housing has significant impact on academic performance among students at the University of Ibadan, Nigeria. Both studies established the existence of causality effect of the quality and adequacy of student housing on the academic performance in the university.

Consistently, it is evidence from our findings that attainment of academic success among undergraduate university students in the study area was not only influenced by the quality of housing that students are provided with but also the socioeconomic and demographic characteristics of parents. 
Our findings clearly showed that the quality of facilities across student hostels was generally below the expected standard, and also inadequately provided. Thus, as identified by Matthew (2014), we also discovered that in order for us not to be biased in judging of university students by their poor academic or unsatisfactory performance, we should take time to ask ourselves a simple but convincing question of how much of the challenges faced by university students must be met before they could graduate with outstanding results? Imperatively, it is evidence from our study's findings that the quality of hostel facilities enjoyed by undergraduate students and the extent of financial supports accessed could enhance their attainment of academic success.

\subsection{Conclusion}

The study was a cross sectional descriptive and investigatory survey that was designed to established the link between parental prominence and academic success and to broaden the affirmation between student housing quality and academic success. Data was sourced through primary approach among final year students of OAU, OOU and AAUA. It was evidence from our study's outcomes that students' academic success in these universities were greatly influenced by how much economic and financial supports they got from their parents. Besides, we also observed that parental sociodemographic attributes, particularly, their marital status, parental gender preference towards education of their children, parent employment status played a significant role in the students' strive towards attainment of academic success. Also, the contributive roles played by quality of student housing could not be underemphasized when it comes how much success was attained by students in their academic pursuits. Therefore, the availability of improved basic housing, auxiliary, enabling housing facilities and affordable standard accommodation would go a long way in improving quality of education, and this would in the long run enhance academic excellence among the students.

\subsection{Recommendation}

Evidence from this study have made the following recommendations inevitable:

1. Since the contribution of financial and economic supports in academic pursuits may not be sidelined, it is imperative that students should be adequately provided with funds in form of scholarships, bursaries and granst particularly those that are from poor households or broken homes.

2. Also, parents should be enlightened more on their gender perceptions towards the education of their children/wards regardless of gender difference. 
3. There is an urgent need to set aside adequate funds for the maintenance of the existing student accommodations. There is also a need to build more student hostels. Building of more hostels is necessary, since it will afford students that are living in off-campus accommodation to be relocated to on-campus accommodation where they may have access to improved housing facilities in a conducive environment.

4. In line with the third recommendation, students should not only be provided with decent accommodation but also with affordable hostels.

\subsection{Acknowledgement}

The authors acknowledged the selfless contribution of Mr. Victor Ogunwobu, who coordinated the execution of the field work among students of Olabisi Onabanjo University. The authors also express their gratitude to Mr. Adeola Oluwafemi and Ms. Oyebode Abiodun for their selfless effort in the coordination and gathering of data in Obafemi Awolowo University and Adekunle Ajasin University.

\section{References:}

1. Adama, J. U., Aghimien, D. O. \& Fabunmi, C. O. (2018). Students' Housing in Private Universities in Nigeria: Influencing Factors and Effect on Academic Performance. International Journal of Built Environment and Sustainability, 5(1).

2. Adeyemo, D. A. (2007). Moderating influence of emotional intelligence on the link between academic self-efficacy and achievement of university students. Psychology \& Developing Societies, 19(2), 199-213

3. Adunola, O. (2011). An Analysis of the Relationship between Class Size and Academic Performance of Students, Ego Booster Books, Ogun State, Nigeria

4. Ajayi, M., Nwosu, A., \& Ajani, Y. (2015). Students'satisfaction with Hostel Facilities in Federal

5. University of Technology, Akure, Nigeria. European Scientific Journal, ESJ, 11(34).

6. Akinpelu, O., P. (2015). Students' Assessment of Hostel Facilities in the Polytechnic Ibadan, Ibadan, Nigeria: Realities and Challenges. Research on Humanities and Social Sciences, 5(17), 74-81

7. Alokan, F.B.; Osakinle, E.O. \& Onijingin, E.O. (2013). The influence of parents' educational background and study facilities on academic performance among secondary school students. Ozean Journal of Social Sciences, 6(2): 27-33. 
8. Amole, Dolapo. (2005). Coping strategies for living in student residential facilities in Nigeria. Environment and behavior, 37(2), 201219.

9. Arum, R., \& Roksa, J. (2011). Academically adrift: Limited learning on college campuses. Chicago, IL: University of Chicago Press.

10. Ayodele, J.B. and Ige, M.A. (2012). Teachers' utilisation as correlate of students' academic performance in senior secondary schools in Ondo State, Nigeria. European Journal of Educational Studies, 4(2), 55-62.

11. Choi, N. (2005). Self-efficacy and self-concept as predictors of college students' academic performance. Psychology in the Schools, 42(2), 197-205. doi:10.1002/pits.20048

12. Conley, D. (1999). Being black, Living in the Red: Race, Wealth, and Social Policy in America. Berkeley, California. University of California Press

13. Daniel, W. (2016). A study of corrupt practices in tertiary institutions in Delta State of Nigeria. JEAH Journal of Education. Arts and Humanity, vol 3 (2), pp, 22-28

14. David, O. (1996)."Barriers to Functional and Qualitative Technology Education in Developing Countries: Nigeria as a Case Study," Paper presented at the Jerusalem International Science and Technology Education conference

15. Dervarics, C. \& O’Brien E. (2011). Back to school: How parents Involvement affects student achievement (full report). Retrieved from http//www.center for publications.com.htm. Accessed on 31 October, 2018.

16. Ekundayo, H.T. (2015). School facilities as correlates of students' achievement in the affective and psychomotor domains of learning. European Scientific Journal, 8(6): 208-215.

17. Fasokun, T. (2010). Policy issues in poverty education through adult education. In Julie Precede (ed.). Adult education and poverty reduction: A global priority. A paper presented and published at the University of Botswana.

18. Grandvaux, Y. (2002) A Literature review of community schools in Africa, Washington, D.C, SARA Project

19. Grave, B. S. (2010). The Effect of Student Time Allocation on Academic Achievement. Ruhr Economic Papers; No 235; RuhrUniversity Bochum (RUB).

20. Kolawole, O. A., \& Boluwatife, A., R. (2016). Assessment of the Factors Influencing Students' Choice of Residence in Nigerian Tertiary Institutions. Sains Humanika, 8(2). 
21. Kuh, G. D., Kinzie, J., Schuh, J. H., Whitt, E. J., and Associates, (2010). Student success in college:

22. Creating conditions that matter. San Francisco, CA: Josey-Bass Publishing

23. Lamborn, Brown, Mounts \& Steinberg (1992). Putting school in perspective: The influence of family, peers extracurricular participation, and part-time work on academic engagement student engagement and achievement in American secondary schools.

24. Lassa, P. (2000). Teacher Production: A focus on Nigeria. The state of education in Nigeria. (pp. 70-83). UNESCO, Abuja.

25. Maina, S. (2013). The Effect of Lecturer's Attitude toward the Performance of Students in Purchasing Management in Ramat Polytechnic Maiduguri. Academic Journal of Interdisciplinary Studies, 2(7), 51.

26. Matthew, I.A. (2014). The challenges of being a student of any Public Tertiary Institution in Nigeria of today, Journals of studies in Education, volume 4 (1), PP: 128-141

27. Memory Q. and Memory, D. (2013). Corrupt Academic Practices: A Tragedy in Nigerian Educational System. Journal of Education and Practice, Vol.4, No.27, 2013

28. Mutsotso, S N and Abenga E. S. B, (2010). Study Methods for Improving Quality Learning and Educational Research and Review Vol. 5 (12), (2010) pp.808 - 813Performance in Higher Education. Available online at http://www.academicjournal.org. Accessed on $31 / 10 / 2018$

29. Nimako, S, \& Bondinuba, F. (2013). Relative importance of student accommodation quality in higher education. Current Research Journal in Social Sciences, 5(4), 134-142.

30. Nirav, S. (2012). What is the relationship between a school and community? Preserve Articles. Retrieved from http://www.preservearticles.com/2012011020535/what-is-therelationship- between-school-and-community.html).

31. Nwanze, C. (2012), Corruption in Nigeria Exposed. Lagos: CSP Publication.

32. Okeyim, M., Ejue, B \& Ekenem, S. (2013). Governance and Corruption in Nigeria: A philo- psychological Analysis. In Net Journal of Social sciences 1 (2) pp 24-32, October

33. Oladiran, O., J. (2013). A Post Occupancy Evaluation of Students' Hostel Accommodation. Journal of Building Performance, 4(1).

34. Olatunji, S. O, Aghimien, D. O, Oke, A. E. and Olushola, E. (2016). Factors Affecting Performance of Undergraduate Students in 
Construction Related Disciplines. Journal of Education and Practice, 7 (13), 55-62.

35. Oluremi, O.F. (2013). Enhancing educational effectiveness in Nigeria through teacher's professional development. European Scientific Journal, 9(28), 422-431.

36. Oluwaseyi, O.B. (2015).The effects of students 'Housing on academic performance at the University of Ibadan in Nigeria, International Journal of Scientific and Engineering Research, Volume 6(3),PP:1118-1132.

37. Oviawe, J.I. (2016). Teachers' effectiveness as correlates of students' academic achievement in basic technology in Nigeria. International Journal of Academic Research in Progressive Education and Development, 5(2), 111-119.

38. Owolabi, B., O. (2015). The Effects of Students' Housing on Academic Performance at the University of Ibadan Nigerian. International Journal of Scientific \& Engineering Research, 6(3), 1118-1132.

39. Oyetunji, A. K. and Abidoye, R. B. (2016). Assessment of the Factors Influencing Students' Choice of Residence in Nigerian Tertiary Institutions. Sains Humanika, 8(2), 39-47

40. Suki, N.M., Chowdhury, I.A. (2015). Student's attitude and satisfaction living in sustainable on-campus hostel, Malaysian Journal of Business and Economics, volume 2 (1), PP: 35-47.

41. The EDUCAUSE top teaching and learning challenges 2009 retrieved on 31 October 2018 (http://www.educause.edu/eli/Challenges).

42. Tucker, C. (1999). African American children a Self-empowerment Approach to Modifying Behaviour Problems and Preventing Academic Failure. Boston: Allyn and Bacon.

43. Yan, Wenfan. (1999) Successful African American students: The Role of parental involvement. Journal of Negro Education, Vol.68 No. 1,

44. Yilmaz-soylu M. \& Akkoyunlu B. (2009).The Effect of Learning Styles on Achievement in different Learning Environments: The Turkish Online Journal of Education Technology (TOJET) Vol.8 (4), pp.44.

45. Zotorvie, J. S. T. (2017). Students' Accommodation and Academic Performance: The Case of Ho Technical University, Ghana. European Scientific Journal, 13(13), 290 - 302. 